\title{
Selection of Alternative Suppliers Using Analytical Hierarchy Process and Technique for Order Preference by Similarity to Ideal Solution
}

\section{Pemilihan Alternatif Pemasok Menggunakan Analytical Hierarchy Process dan Technique for Order Preference by Similarity to Ideal Solution}

\author{
Melani Magdalena Hutabarat ${ }^{1}$, Agus Ristono $^{1 *}$, Sutrisno ${ }^{1}$ \\ ${ }^{1}$ Jurusan Teknik Industri, Fakultas Teknik Industri, UPN "Veteran” Yogyakarta \\ Jl. SWK 104, Condongcatur, Depok, Sleman, Yogyakarta \\ email:melanibarat17@gmail.com,agus.ristono@upnyk.ac.id \\ doi: https://doi.org/10.31315/opsi.v14i2.5411
}

Received: $30^{\text {th }}$ August 2021; Revised: $3^{\text {rd }}$ November 2021; Accepted: $3^{\text {rd }}$ November 2021; Available online: $21^{\text {st }}$ December 2021; Published regularly: December 2021

\begin{abstract}
The industry of garment is an industry that focuses on clothing production. Along with the times, development models and functional clothing is increasingly varied. Therefore company will try to determine the best supplier. Based on observations garment industry in the Central Java, it was found problems related to continuity of fabric supply from main suppliers. When demand soars, demand for cloth supply also increases. However, the availability of fabric supplies owned by main suppliers are not able to fulfil the needs of garment industry. Therefore, garment industry requires alternative backup suppliers who are able to meet the supply of fabric when the main supplier is inadequate. Supplier selection will be carried out using the Analytical Hierarchy Process (AHP) method in weighting and Technique for Others Preference by Similarity to Ideal Solution (TOPSIS) method to sort priority supplier. This supplier priority will be used as an alternative supplier that will meet the availability of fabric supply.
\end{abstract}

Keywords: AHP; TOPSIS; supplier selection; garment industry

\begin{abstract}
ABSTRAK
Industri garmen merupakan industri yang berfokus pada pembuatan pakaian. Seiring berkembangnya zaman, perkembangan model dan fungsi pakaian semakin bervariasi. Salah satu upaya yang dilakukan perusahaan adalah menentukan pemasok yang terbaik. Berdasarkan observasi pada industri garmen di Jawa Tengah ditemukan masalah terkait kontinuitas pasokan kain dari pemasok utama. Ketika permintaan melonjak maka kebutuhan pasokan kain juga. Namun ketersediaan pasokan kain yang dimiliki oleh pemasok utama tidak mampu memenuhi kebutuhan industri garmen. Oleh karena itu industri garmen memerlukan alternatif pemasok cadangan yang mampu memenuhi pasokan kain ketika pemasok utama tidak memadai. Pemilihan pemasok akan dilakukan dengan menggunakan metode Analytical Hierarchy Process (AHP) dalam pembobotan dan metode Technique for Others Preference by Similarity to Ideal Solution (TOPSIS) dalam pemeringkatan urutan prioritas pemasok. Urutan prioritas pemasok ini akan digunakan sebagai alternatif pemasok yang akan mencukupi ketersediaan pasokan kain.
\end{abstract}

Kata Kunci: AHP; TOPSIS; pemilihan pemasok; industri garmen 


\section{PENDAHULUAN}

Industri garmen merupakan industri yang berfokus memproduksi pakaian jadi secara massal. Berdasarkan hasil observasi pada industri garmen di Jawa Tengah, yaitu PT.Bina Busana Internusa, PT. Ungaran Sari Garment, dan PT. Sri Rejeki Isman Tbk ditemukan masalah pada suatu lini produksi. Lini produksi tersebut memproduksi pakaian jadi merek luar negeri. Masalah yang terjadi, yaitu ketika terjadi lonjakan permintaan menyebabkan produk yang dihasilkan melebihi kuantitas normal. Hal ini menyebabkan meningkatnya pasokan bahan baku yang tidak dapat dipenuhi oleh pemasok utama. Kemampuan pemasok utama inilah yang menyebabkan proses produksi terganggu. Ketidakseimbangan antara permintaan dengan ketersediaan bahan baku merupakan kendala yang harus diatasi.

Salah satu upaya yang dilakukan adalah menentukan bagaimana sistem pemilihan pemasok cadangan bagi industri garmen Jawa Tengah khususnya PT. Bina Busana Internusa, PT. Ungaran Sari Garment, dan PT. Sri Rejeki Isman Tbk. dengan memakai metode Analytical Hierarchy Process (AHP) dan Technique for Others Preference by Similarity to Ideal Solution (TOPSIS). Pemilihan pemasok akan membantu perusahaan dalam menentukan urutan prioritas pemasok cadangan bagi industri garmen. Pemasok cadangan akan bertugas memenuhi kekurangan pasokan jika pemasok utama tidak memiliki ketersediaan pasokan. Terdapat tujuh alternatif pemasok, yaitu Sunny Fashion Textile, Ltd; LU Feng Co., Ltd; Mastex Inc; Fineline Technologies, Silverreed Holdings, Ltd; Alok Industries, Ltd; dan Azuma Co., Ltd.

Pemilihan pemasok industri garmen yang baik akan membangun kemitraan strategis dan kolaboratif (Ulutas, 2019). Beberapa alternatif pemasok menyulitkan perusahan dalam menentukan pemasok cadangan. Oleh karena itu diperlukan pengambilan keputusan. Alazzawi and Zak, (2020) menyatakan bahwa metodologi pengambilan keputusan dibangun diatas tujuan pemangku kepentingan dengan menetapkan kriteria. Acar et al., (2016) menjelaskan bahwa terdapat faktor klasik dan hijau yang dapat digunakan untuk menentukan kriteria keputusan yang sesuai.

Setiap alternatif pemasok memiliki kriteria unggulan yang berbeda. Perbedaan kriteria ini juga menyulitkan pengambil keputusan dalam menentukan urutan prioritas pemasok cadangan yang akan digunakan. Oleh sebab itu, diperlukan kriteria yang sama untuk dijadikan standar dalam pemilihan alternatif pemasok. Berdasarkan penelitian (Khurunin, 2021) didapatkan 54 kriteria yang dikumpulkan dari berbagai referensi dan diolah menggunakan analisis faktor yang menghasilkan 4 kriteria utama, yaitu kriteria produksi, kinerja, pasokan, dan kriteria teknologi informasi. Nilai bobot dari kriteria utama diperoleh sebesar 0,$264 ; 0,245 ; 0,245$; dan 0,245 yang didapatkan dengan menggunakan bobot rata-rata geometrik.

Nilai bobot yang dihasilkan menunjukkan kesamaan antara kriteria dua (kinerja), tiga (pasokan), dan empat (teknologi informasi). Persamaan nilai bobot tersebut menunjukkan bahwa nilai bobot kurang merepresentasikan penilaian sebenarnya. Berdasarkan kelemahan penelitian (Khurunin, 2021), penelitian ini bermaksud menyempurnakannya dengan menggunakan metode Analytical Hierarchy Process dalam pembobotan dan metode Technique for Others Preference by Similarity to Ideal Solution dalam pemeringkatan urutan prioritas pemasok.

\section{METODE}

Metodologi yang diusulkan akan diterapkan pada PT.Bina Busana Internusa, PT. Ungaran Sari Garment, dan PT. Sri Rejeki Isman Tbk. Waktu pelaksanaan dimulai pada bulan Mei 2021 hingga bulan Juni 2021. Penelitian menggunakan alat dan bahan diantaranya studi literatur, kuesioner, dan perangkat lunak. Kuesioner diisi oleh tim yang ditunjuk oleh masing-masing perusahaaan. Sehingga terdapat 3 kuesioner yang mewakili penilaian setiap tim perusahaan. Setiap tim terdiri dari 5-7 pegawai yang ahli menangani pemasok. Setiap ahli akan berdiskusi untuk menghasilkan penilaian suatu kuesioner.

Penelitian ini dilakukan berdasarkan observasi dari ketiga perusahaan. Observasi dilakukan dengan menanyakan kendala apa yang dialami oleh perusahaan. Berdasarkan observasi maka ditemukan masalah pada pemasok utama. Pemasok utama tidak mampu memenuhi pasokan bahan baku ketika terjadi lonjakan permintaan. $\mathrm{Hal}$ ini tentu mengganggu proses produksi. Oleh karena itu diperlukan pemasok cadangan yang mampu memenuhi kekurangan pasokan tersebut.

Penelitian dilakukan dengan menyebarkan kuesioner kepada masing-masing perusahaan 
melalui surat elektronik. Setiap perusahaan akan menerima satu kuesioner pemilihan pemasok yang nantinya akan dinilai oleh sebuah tim yang ahli di bidang pemasok dan bahan baku. Setiap tim tersebut terdiri dari beberapa anggota yang kompeten. Tim tersebut akan mendiskusikan jawaban kuesioner dengan sesama anggota tim lainnya. Kuesioner yang telah diisi akan dikirimkan kembali kepada peneliti untuk diolah. Pengolahan dilakukan secara manual menggunakan perangkat lunak pengolah data, yaitu Microsoft Excel. Hasil yang didapatkan akan diberikan kepada perusahaan sebagai saran untuk mengatasi masalah yang terjadi.

Pemilihan pemasok dinilai berdasarkan kemampuan pemasok dalam memenuhi kriteria yang ditetapkan. Kriteria tersebut kemudian dibobotkan menggunakan perbandingan berpasangan. Data yang diperlukan dalam pembobotan berupa data kriteria, alternatif pemasok, dan penilaian para ahli. Langkah pengolahan data menggunakan Analytical Hierarchy Process (AHP) diantaranya menyusun masalah keputusan ke dalam hierarki dengan menentukan daftar tujuan, kriteria, dan alternatif, membuat matriks perbandingan berpasangan, menghitung konstruksi matriks berpasangan dan menghitung rasio konsistensi.

Nilai bobot hasil pengolahan dan nilai keputusan yang didapatkan dari kuesioner kemudian diolah menggunakan Technique for Others Preference by Similarity to Ideal Solution (TOPSIS). Metode TOPSIS digunakan untuk memilih sejumlah alternatif dengan menggunakan pengukuran jarak Euclidean (Mavi et al., 2016). Data yang diperlukan berupa bobot kriteria, alternatif pemasok, dan penilaian para ahli. Langkah pengolahan data TOPSIS diantaranya membuat normalisasi matriks keputusan, membuat matriks ternormalisasi berbobot, menghitung matriks solusi ideal negatif dan positif, menghitung jarak matriks solusi ideal positif dan negatif terhadap alternatif, menghitung nilai preferensi, dan memilih alternatif dengan nilai paling mendekati solusi ideal positif (Rouyendegh and Saputro, 2014).

Hasil pemeringkatan yang dihasilkan merupakan urutan prioritas pemasok. Pemasok cadangan dijadikan pengganti pemasok utama dalam memenuhi pasokan bahan baku. Hal ini tentu akan membantu mengoptimalkan produksi, menjaga kualitas produk, dan memenuhi kebutuhan pasar. Data yang dihasilkan akan diterima jika nilai bobot yang divalidasi memiliki nilai consistensy ratio $<0,1$ (Saaty, 1993). Jika nilai consistensy ratio $<0,1$ maka penelitian tersebut menunjukkan bahwa ketidak konsistenan dalam pengisian kuesioner dapat diterima.

\section{HASIL DAN PEMBAHASAN}

\subsection{Data Komponen Kritis}

Data yang digunakan merupakan data struktur hierarki yang ditunjukkan pada Gambar 1. Data tersebut berupa data tujuan, kriteria, alternatif pemasok, dan nilai keputusan kriteria terhadap setiap alternatif. Data nilai keputusan ditunjukkan pada Tabel 3. Perhitungan penelitian dilakukan dengan menggunakan metode Analytical hierarchy process (AHP) dan Technique for Others Preference by Similarity to Ideal Solution (TOPSIS). Perhitungan menggunakan metode AHP ditunjukkan sebagai berikut (Pratiwi, 2016):

a. Perhitungan matriks nilai kriteria utama dapat dilihat pada Tabel 1 dengan persamaan sebagai berikut.

$$
\text { Eigen Vector }=\frac{a_{i j}}{\sum_{i=1}^{n} a_{i j}}
$$

b. Perhitungan nilai Eigen Value $(\lambda)$ dapat dilihat pada Tabel 2 dengan persamaan sebagai berikut.

Eigen Value $\mathrm{A}=\frac{\text { Jumlah }}{\text { Eigen Vector }}$

c. Perhitungan matriks nilai rasio konsistensi (Saaty, 1997) dapat dilihat pada Tabel 2 dengan persamaan sebagai berikut.

Consistency Index $=((\lambda$ maks- $\mathrm{n}) / \mathrm{n}-1)$

Consistency Ratio $=\frac{\text { Consistency Index }}{\text { Random Index }}(4)$

d. Membuat perbandingan nilai bobot penelitian (Khurunin, 2021) dengan sekarang dapat dilihat pada Gambar 3. Gambar tersebut menunjukkan perbedaan nilai bobot kriteria.

Notasi dari pengolahan data AHP diantaranya $a_{i j}$ merupakan hasil dari penjumlahan baris, $\sum_{i=1}^{n} a_{i j}$ merupakan elemen prioritas relatif, eigen vector merupakan hasil bagi antara $a_{i j}$ dengan $\sum_{i=1}^{n} a_{i j}$, eigen value merupakan jumlah hasil dibagi dengan eigen vector, $\lambda$ maks merupakan nilai rata-rata dari eigen value, $n$ merupakan banyak kriteria, consistency index merupakan nilai indeks konsistensi, random index merupakan nilai acak yang sudah ditetapkan, consistency ratio merupakan hasil akhir dari perhitungan.

Pengolahan data menggunakan metode AHP juga dilakukan dengan menggunakan 
software Super Decision. Pemilihan software ini dikarenakan software lebih mudah dioperasikan, memberikan hasil yang akurat, serta dapat menyelesaikan masalah yang lebih kompleks. Struktur hierarki menggunakan Super Decision dapat dilihat pada Gambar 2. Perbandingan antara pengolahan data menggunakan perhitungan manual (Microsoft Excel) dengan pengolahan data menggunakan software (Super Decision) dilakukan agar dapat diketahui bagaimana perbedaan urutan prioritas pemasok yang dihasilkan yang dapat dilihat pada Tabel 7 dan Tabel 8.

Perhitungan menggunakan metode TOPSIS diantaranya (Sakthivel et al., 2015):

a. Perhitungan normalisasi matriks keputusan dapat dilihat pada Tabel 4 dengan persamaan sebagai berikut.

$r_{i j}=\frac{x_{i j}}{\sqrt{\sum_{i=1}^{m} x_{i j}^{2}}}$

b. Perhitungan matriks ternormalisasi berbobot dapat dilihat pada Tabel 5 dengan persamaan sebagai berikut.

$Y_{i j}=w_{i} \times r_{i j}$

c. Perhitungan jarak nilai setiap alternatif dengan solusi ideal positif dan negatif dapat dilihat pada Tabel 6 dengan persamaan sebagai berikut.

$$
\begin{aligned}
& D_{i}^{+}=\sqrt{\sum_{i=1}^{n}\left(y_{i j}-y_{i}^{+}\right)^{2}} \\
& D_{i}^{-}=\sqrt{\sum_{i=1}^{n}\left(y_{i j}-y_{i}^{-}\right)^{2}}
\end{aligned}
$$

d. Perhitungan nilai preferensi dapat dilihat pada Tabel 7 dengan persamaan sebagai berikut.

$V_{A}=\frac{D_{i}^{-}}{D_{i}^{+}+D_{i}^{-}}$

e. Membuat perbandingan urutan prioritas pemasok cadangan penelitian (Khurunin,
2021) dengan penelitian sekarang dapat dilihat pada Gambar 4.

f. Perhitungan uji sensitifitas dilakukan dengan data yang berbeda namun metode yang sama. Perbedaan data masukan disesuaikan dengan skenario. Skenario 1 tidak menggunakan kuesioner PT Ungaran Sari Garment dapat dilihat pada Gambar 5, Skenario 2 tidak menggunakan kuesioner PT Sri Rejeki Isman Tbk dapat dilihat pada Gambar 6, Skenario 3 tidak menggunakan kuesioner PT Bina Busana Internusa dapat dilihat pada Gambar 7, Skenario 4 hanya menggunakan kuesioner PT Bina Busana Internusa dapat dilihat pada Gambar 8, Skenario 5 hanya menggunakan kuesioner PT Sri Rejeki Isman Tbk dapat dilihat pada Gambar 9, Skenario 6 hanya menggunakan kuesioner PT Ungaran Sari Garment dapat dilihat pada Gambar 10.

g. Melakukan perbandingan nilai rasio konsistensi yang ditunjukkan pada Tabel 10 dan Gambar 11. Kemudian melakukan perbandingan urutan prioritas pemasok dari seluruh skenario ditunjukkan pada Tabel 11 dan Gambar 12.

Notasi dari pengolahan menggunakan TOPSIS diantaranya $x_{i j}$ merupakan nilai matriks keputusan, $\sqrt{\sum_{i=1}^{m} x_{i j}^{2}}$ merupakan hasil akar pangkat per kriteria, $r_{i j}$ merupakan hasil bagi antara $x_{i j}$ dengan $\sqrt{\sum_{i=1}^{m} x_{i j}^{2}}, Y_{i j}$ merupakan nilai matriks ternormalisasi berbobot, $w_{i}$ merupakan nilai bobot kriteria, $y_{i}^{+}$merupakan nilai maksimal setiap kriteria, $y_{i}^{-}$merupakan nilai minimal setiap kriteria, $D_{i}^{+}$merupakan solusi ideal positif, $D i^{-}$merupakan solusi ideal negatif. $V_{A}$ merupakan nilai preferensi alternatif pemasok.

\begin{tabular}{|c|c|c|c|c|c|c|}
\hline Kriteria & Produksi & Kinerja & Pasokan & Teknologi & Jumlah & Eigen vector \\
\hline Produksi & 0,1189 & 0,0996 & 0,1088 & 0,1314 & 0,4587 & 0,1147 \\
\hline Kinerja & 0,1887 & 0,1581 & 0,1371 & 0,1618 & 0,6457 & 0,1614 \\
\hline Pasokan & 0,2377 & 0,2510 & 0,2176 & 0,2039 & 0,9102 & 0,2275 \\
\hline Teknologi & 0,4547 & 0,4913 & 0,5366 & 0,5028 & 1,9855 & 0,4964 \\
\hline Total & 1,0000 & 1,0000 & 1,0000 & 1,0000 & 4,0000 & 1,0000 \\
\hline \multicolumn{7}{|c|}{ Tabel 2. Matriks penjumlahan setiap baris } \\
\hline Kriteria & Produksi & Kinerja & Pasokan & Teknologi & Jumlah & Eigen value $(\lambda)$ \\
\hline Produksi & 0,1147 & 0,1017 & 0,1138 & 0,1297 & 0,4599 & 4,0104 \\
\hline Kinerja & 0,1820 & 0,1614 & 0,1433 & 0,1597 & 0,6465 & 4,0053 \\
\hline Pasokan & 0,2293 & 0,2562 & 0,2275 & 0,2013 & 0,9144 & 4,0185 \\
\hline Teknologi & 0,4387 & 0,5016 & 0,5612 & 0,4964 & 1,9978 & 4,0249 \\
\hline \multirow[t]{4}{*}{ Total } & 0,9648 & 1,0209 & 1,0458 & 0,9871 & 4,0186 & 16,0591 \\
\hline & & & & & IR & 0.9000 \\
\hline & & & & & CI & 0.0049 \\
\hline & & & & & CR & 0.0055 \\
\hline
\end{tabular}

Tabel 1. Matriks nilai kriteria utama 
Tabel 3. Nilai keputusan

\begin{tabular}{lcccc}
\hline \multicolumn{1}{c}{ Perusahaan pemasok } & Produksi & Kinerja & Pasokan & Teknologi \\
\hline Sunny Fashion Textile, Ltd & 3.6342 & 3.3019 & 2.8845 & 3.3019 \\
LU Feng Co., Ltd & 2.6207 & 3.5569 & 3.3019 & 2.6207 \\
Mastex Inc & 3.3019 & 3.9149 & 3.3019 & 4.3089 \\
Fineline Technologies & 2.6207 & 3.6342 & 3.9149 & 3.6342 \\
Silverreed Holdings, Ltd & 2.6207 & 3.6342 & 4.3089 & 3.0000 \\
Alok Industries, Ltd & 2.8845 & 2.2894 & 3.0000 & 2.6207 \\
Azuma Co., Ltd & 4.6416 & 4.6416 & 3.3019 & 3.3019 \\
\hline Akar hasil pangkat per kriteria & 8.6360 & 9.5959 & 9.1608 & 8.7359 \\
\hline
\end{tabular}

Tabel 4. Normalisasi matriks keputusan

\begin{tabular}{lcccc}
\hline \multicolumn{1}{c}{ Perusahaan pemasok } & Produksi & Kinerja & Pasokan & Teknologi \\
\hline Sunny Fashion Textile, Ltd & 0,4208 & 0,3441 & 0,3149 & 0,3780 \\
LU Feng Co., Ltd & 0,3035 & 0,3707 & 0,3604 & 0,3000 \\
Mastex Inc & 0,3823 & 0,4080 & 0,3604 & 0,4932 \\
Fineline Technologies & 0,3035 & 0,3787 & 0,4273 & 0,4160 \\
Silverreed Holdings, Ltd & 0,3035 & 0,3787 & 0,4704 & 0,3434 \\
Alok Industries, Ltd & 0,3340 & 0,2386 & 0,3275 & 0,3000 \\
Azuma Co., Ltd & 0,5375 & 0,4837 & 0,3604 & 0,3780 \\
\hline
\end{tabular}

Tabel 5. Matriks ternormalisasi berbobot

\begin{tabular}{lcccc}
\hline \multicolumn{1}{c}{ Perusahaan pemasok } & Produksi & Kinerja & Pasokan & Teknologi \\
\hline Sunny Fashion Textile, Ltd & 0,0483 & 0,0555 & 0,0716 & 0,1876 \\
LU Feng Co., Ltd & 0,0348 & 0,0598 & 0,0820 & 0,1489 \\
Mastex Inc & 0,0438 & 0,0659 & 0,0820 & 0,2448 \\
Fineline Technologies & 0,0348 & 0,0611 & 0,0972 & 0,2065 \\
Silverreed Holdings, Ltd & 0,0348 & 0,0611 & 0,1070 & 0,1705 \\
Alok Industries, Ltd & 0,0383 & 0,0385 & 0,0745 & 0,1489 \\
Azuma Co., Ltd & 0,0616 & 0,0781 & 0,0820 & 0,1876 \\
\hline Max & 0.0616 & 0.0781 & 0.1070 & 0.2448 \\
Min & 0.0348 & 0.0385 & 0.0716 & 0.1489 \\
\hline
\end{tabular}

Tabel 6. Jarak nilai setiap alternatif dengan solusi ideal positif dan negatif

\begin{tabular}{lccc}
\hline \multicolumn{1}{c}{ Perusahaan pemasok } & $\mathbf{D}_{\mathbf{i}}^{+}$ & $\mathbf{D}_{\mathbf{i}}{ }^{-}$ & $\mathbf{D}_{\mathbf{i}}^{+}+\mathbf{D}_{\mathbf{i}}{ }^{-}$ \\
\hline Sunny Fashion Textile, Ltd & 0,0722 & 0,0444 & 0,1166 \\
LU Feng Co., Ltd & 0,1043 & 0,0237 & 0,1280 \\
Mastex Inc & 0,0330 & 0,1007 & 0,1337 \\
Fineline Technologies & 0,0507 & 0,0670 & 0,1177 \\
Silverreed Holdings, Ltd & 0,0809 & 0,0472 & 0,1281 \\
Alok Industries, Ltd & 0,1112 & 0,0045 & 0,1157 \\
Azuma Co., Ltd & 0,0624 & 0,0624 & 0,1248 \\
\hline
\end{tabular}

Tabel 7. Nilai preferensi kriteria utama

\begin{tabular}{lcc}
\hline \multicolumn{1}{c}{ Perusahaan pemasok } & $\mathbf{V}_{\mathbf{A}}$ & Peringkat \\
\hline Mastex Inc & 0,7529 & 1 \\
Fineline Technologies & 0,5690 & 2 \\
Azuma Co., Ltd & 0,4998 & 3 \\
Sunny Fashion Textile, Ltd & 0,3807 & 4 \\
Silverreed Holdings, Ltd & 0,3686 & 5 \\
LU Feng Co. , Ltd & 0,1852 & 6 \\
Alok Industries, Ltd & 0,0391 & 7 \\
\hline
\end{tabular}


Opsi

Vol 14 No 2 December 2021

Tabel 8. Laporan hasil menggunakan Super Decision

\begin{tabular}{|c|c|c|c|c|c|}
\hline Alternatives & Total & Normal & Ideal & Ranking \\
\hline \hline Alok Industries, Ltd & 0.0770 & 0.1540 & 0.7843 & 6 \\
\hline \hline Fineline Technologies & 0.0982 & 0.1963 & 1.0000 & 1 \\
\hline \hline LU Feng Co., Ltd & 0.0812 & 0.1624 & 0.8275 & 5 \\
\hline \hline Mastex Inc & 0.0812 & 0.1624 & 0.8275 & 2 \\
\hline Silverreed Holdings, Ltd & 0.0812 & 0.1624 & 0.8275 & 4 \\
\hline \hline Sunny Fashion & 0.0812 & 0.1624 & 0.8275 & 3 \\
\hline
\end{tabular}

Tabel 9. Perbandingan nilai bobot kriteria utama

\begin{tabular}{lccc}
\hline \multicolumn{1}{c}{ Kriteria } & $\begin{array}{c}\text { Penelitian Terdahulu (\%) } \\
\text { (Khurunin, 2021) }\end{array}$ & $\begin{array}{c}\text { Penelitian Sekarang (\%) } \\
\text { (Microsoft Excel) }\end{array}$ & $\begin{array}{c}\text { Penelitian Sekarang (\%) } \\
\text { (Super Decision) }\end{array}$ \\
\hline Produksi & 26 & 11,47 & 11,45 \\
Kinerja & 24 & 16,14 & 16,09 \\
Pasokan & 25 & 22,75 & 22,75 \\
Teknologi Informasi & 25 & 49,64 & 49,72 \\
\hline
\end{tabular}

Tabel 10. Perbandingan nilai Consistency Ratio dari seluruh skenario

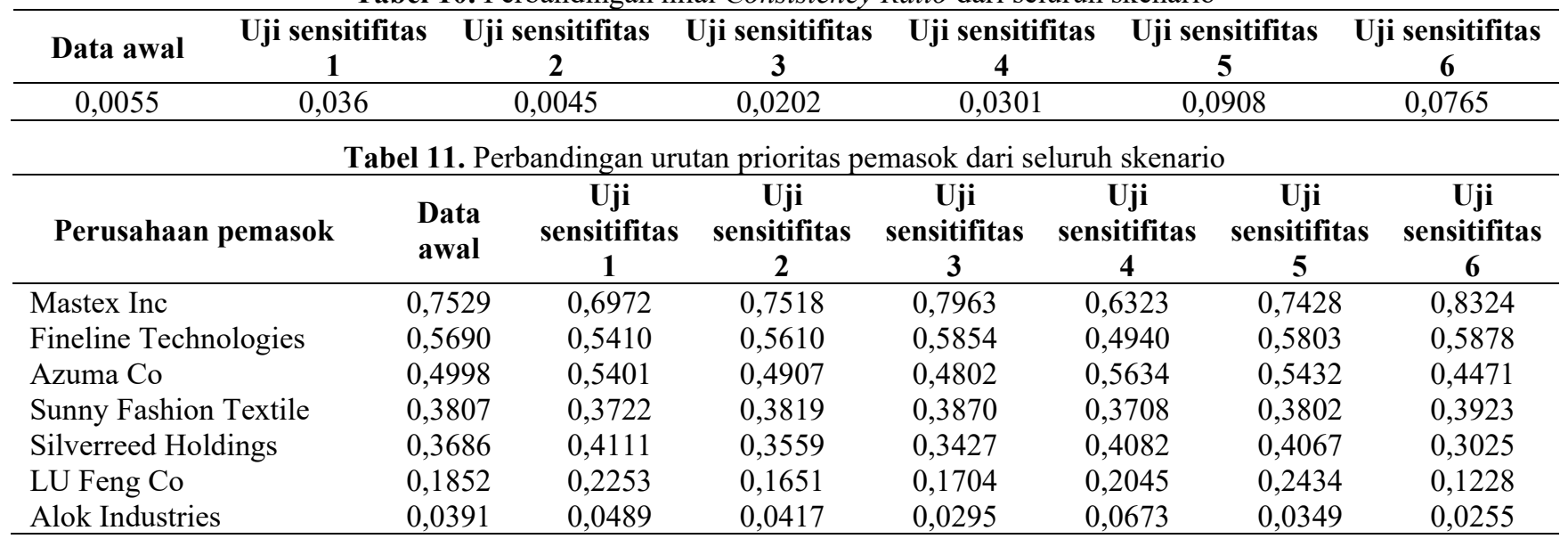

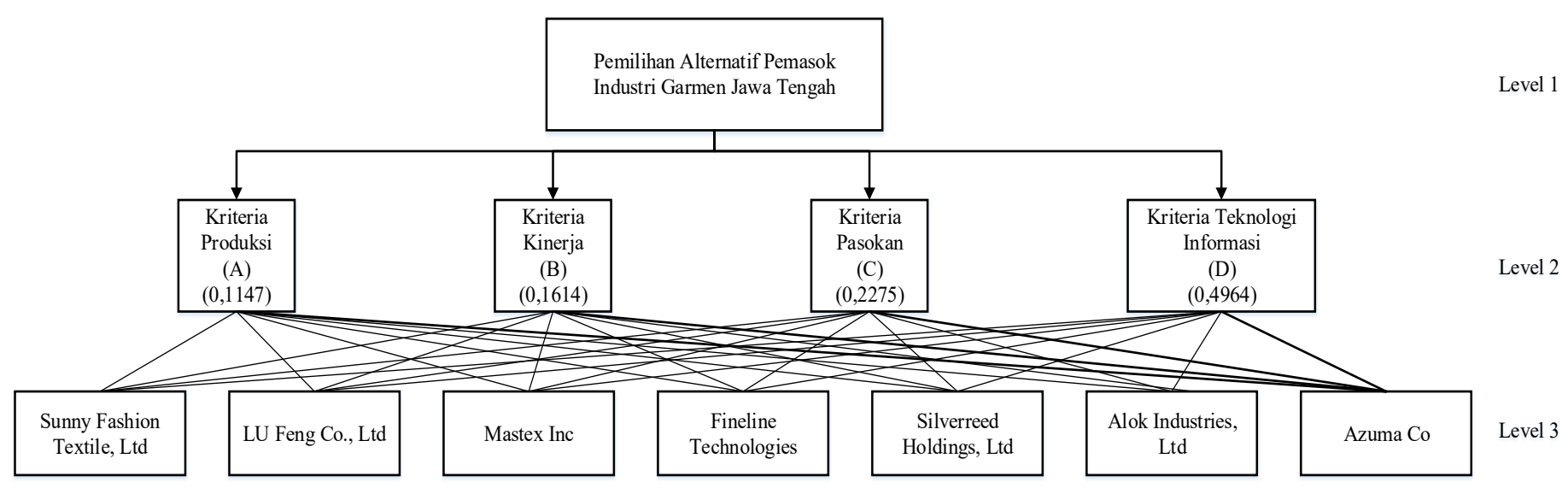

Gambar 1. Struktur hierarki pemilihan pemasok 
Opsi

Vol 14 No 2 December 2021
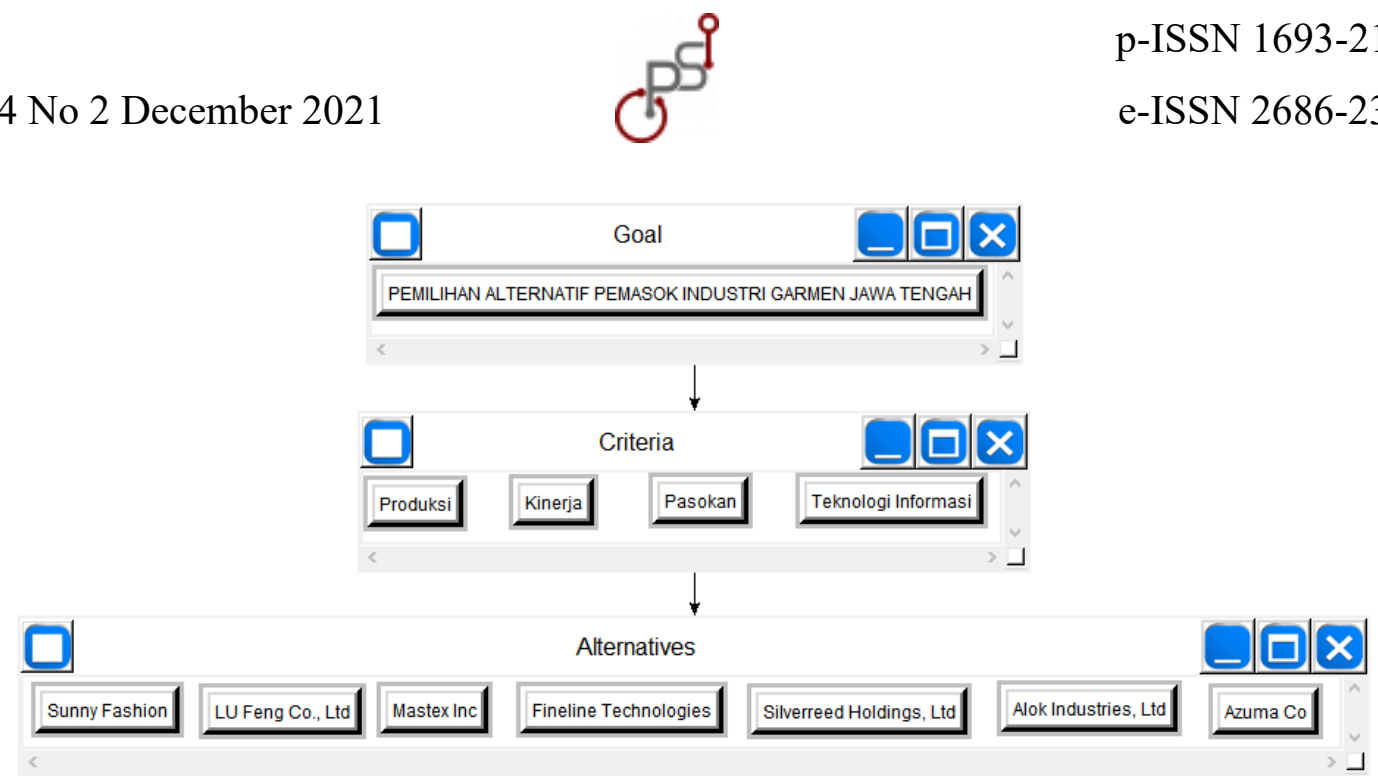

Gambar 2. Struktur hierarki pemilihan pemasok menggunakan Super Decision

NILAI BOBOT KRITERIA

घProduksi $\quad$ Kinerja $\quad$ Pasokan $\quad$ Teknologi Informasi
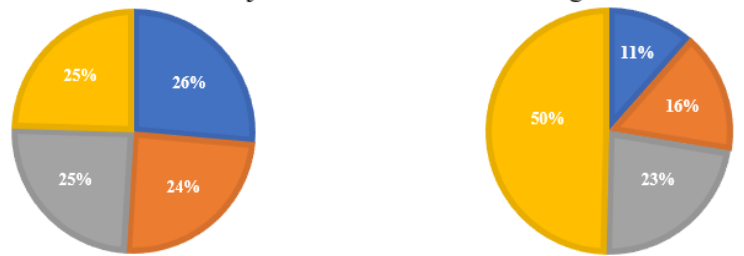

Penelitian (Khurunin, 2021)

Penelitian Sekarang

Gambar 3. Perbandingan nilai bobot kriteria

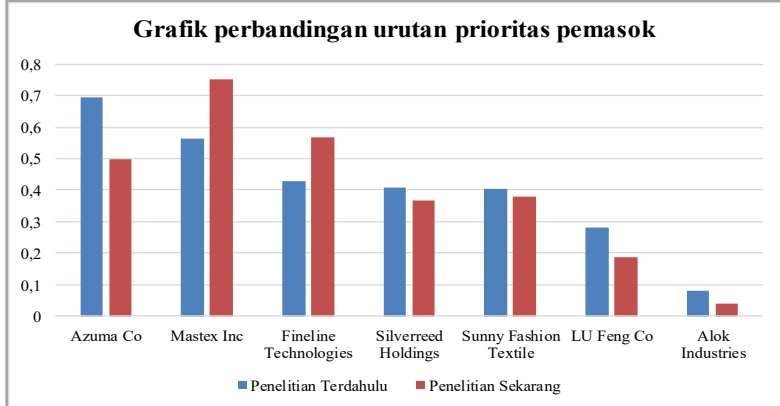

Gambar 4. Grafik perbandingan urutan prioritas pemasok

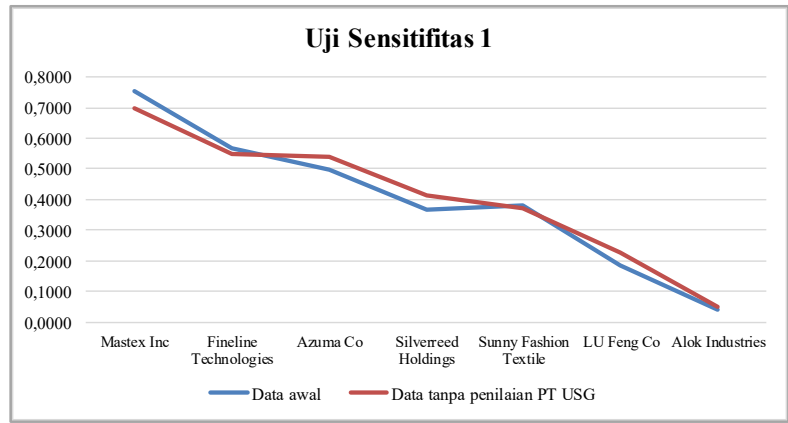

Gambar 5. Grafik uji sensitifitas 1 


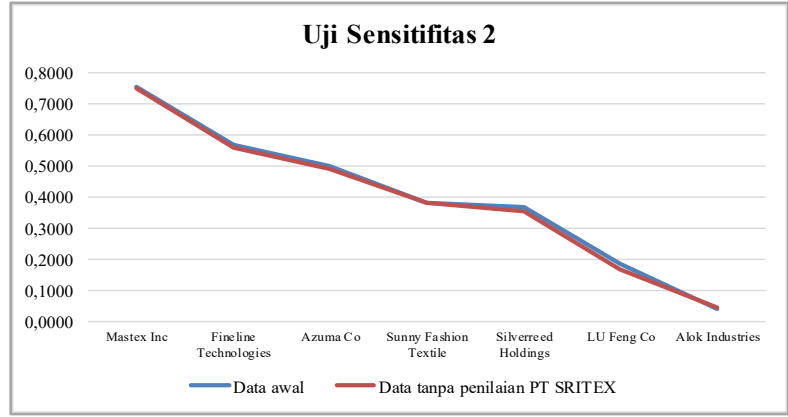

Gambar 6. Grafik uji sensitifitas 2

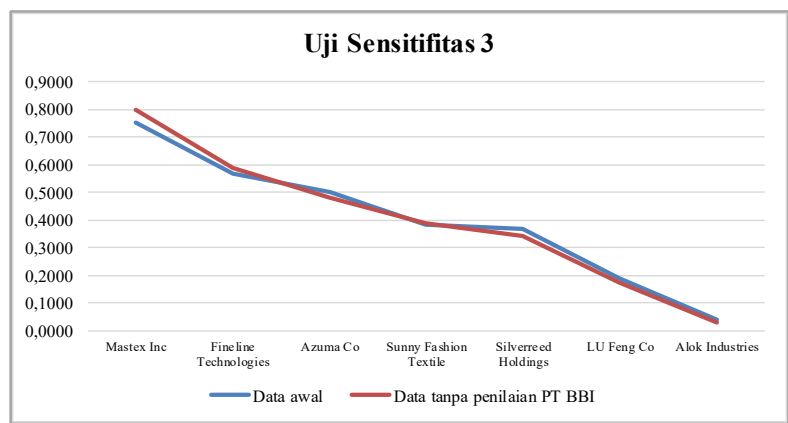

Gambar 7. Grafik uji sensitifitas 3

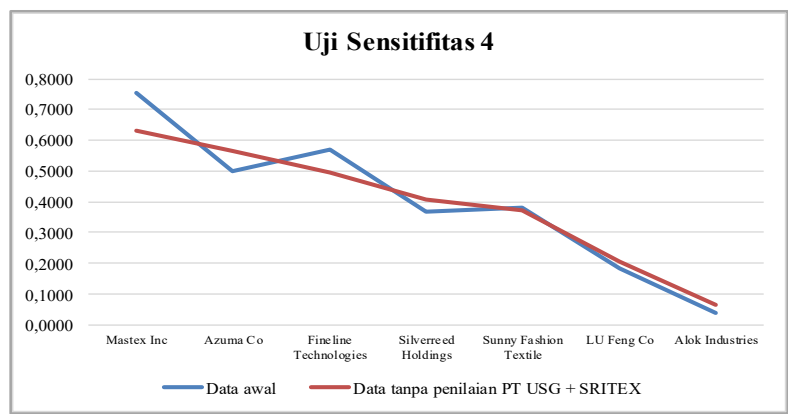

Gambar 8. Grafik uji sensitifitas 4

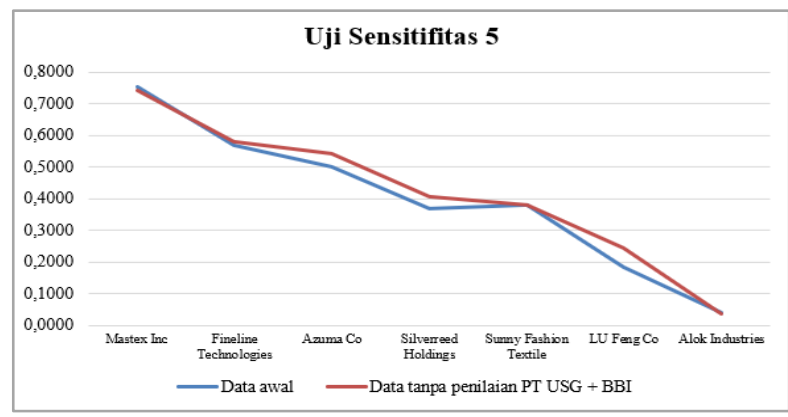

Gambar 9. Grafik uji sensitifitas 5 


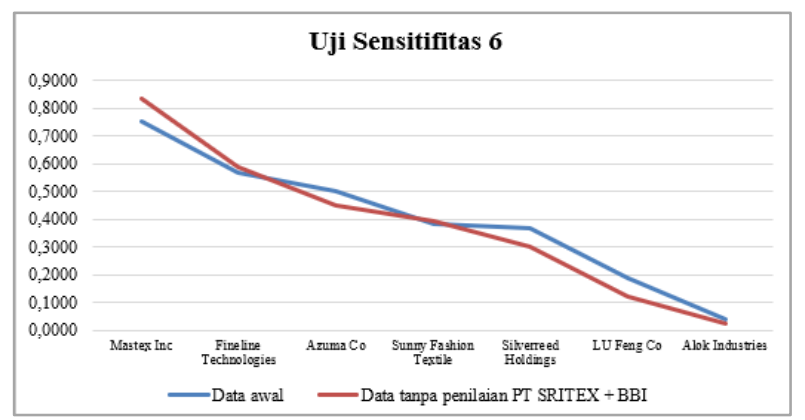

Gambar 10. Grafik uji sensitifitas 6

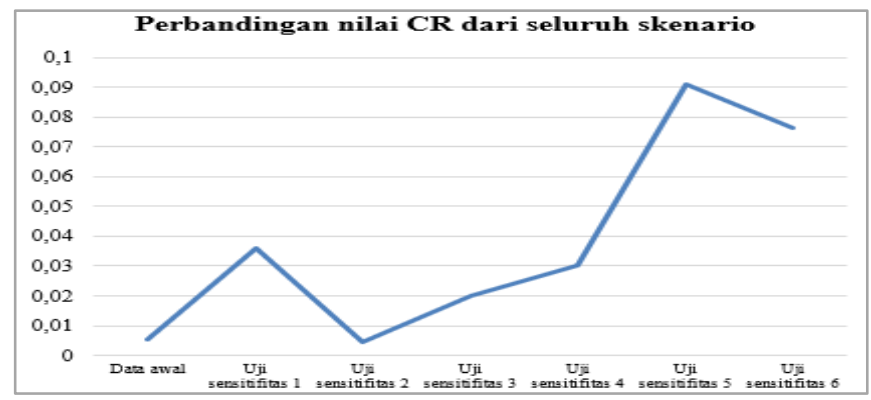

Gambar 11. Grafik uji rasio konsistensi seluruh skenario

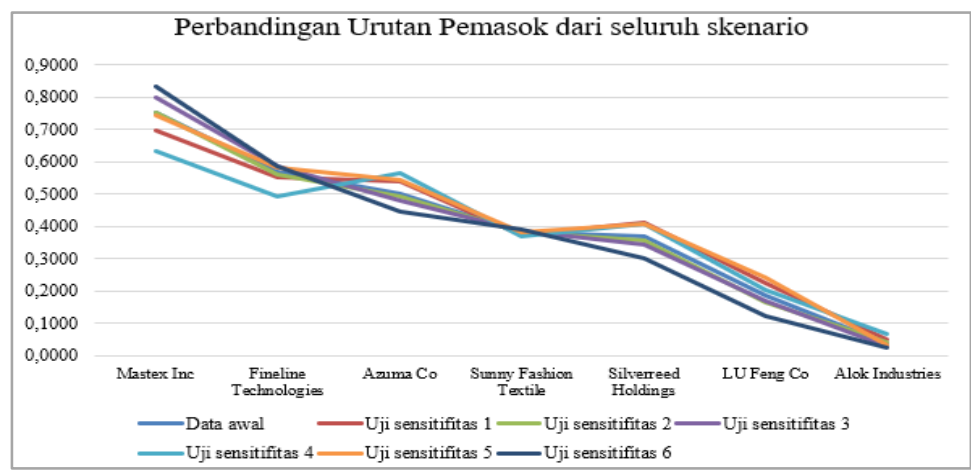

Gambar 12. Grafik perbandingan urutan pemasok seluruh skenario

\subsection{Hasil dan Pembahasan}

Pada penelitian (Khurunin, 2021) pembobotan kriteria diolah menggunakan metode bobot rata-rata geometrik. Nilai bobot yang dihasilkan sebesar 0,$264 ; 0,245 ; 0,245$; dan 0,245 . Hal ini menunjukkan terjadi kesamaan antara kriteria dua, tiga, dan empat. Kesamaan nilai ini disebabkan cara penilaian responden yang kurang konsisten dalam memberikan penilaian. Responden memberikan nilai secara langsung terhadap setiap kriteria tanpa membandingkan terlebih dahulu dengan kriteria lainnya. Kesamaan nilai bobot tersebut menunjukkan bahwa nilai bobot kurang merepresentasikan penilaian yang sebenarnya karena keputusan yang diberikan responden dapat bersifat inkonsistensi. Pada penelitian saat ini, kriteria dibobotkan dengan menggunakan metode Analytical Hierarchy Process (AHP) dan menghasilkan nilai bobot sebesar 0,$1147 ; 0,1614$; 0,2275 ; dan 0,4964. Nilai bobot tersebut menunjukkan bahwa tidak terdapat kesamaan nilai antar kriterianya. Sehingga hasil yang didapatkan juga lebih merepresentasikan penilaian sebenarnya. Dalam perhitungan nilai bobot menggunakan AHP juga telah divalidasi dengan menghitung nilai rasio konsistensi sehingga dapat diketahui apakah nilai bobot yang dihasilkan bersifat konsisten atau tidak. Sementara nilai bobot yang dihasilkan menggunakan Super Decision senilai 0,1145; 0,$1601 ; 0,2275$; dan 0,4972 . Sehingga perbedaan nilai bobot kriteria utama dapat dilihat pada Tabel 9.

Urutan prioritas pemasok diolah menggunakan data masukan berupa nilai bobot 
kriteria hasil pengolahan data dan nilai keputusan yang diperoleh dari pengambil keputusan. Terdapat perbedaan nilai bobot yang digunakan sebagai bahan pengolahan pada pemeringkatan pemasok. Perbedaan bobot ini akan berpengaruh pada urutan prioritas pemasok yang akan dihasilkan. Pada penelitian (Khurunin, 2021) didapatkan urutan prioritas pemasok sebagai berikut Azuma Co, Mastex Inc, Fineline Technologies, Silverreed Holdings, Sunny Fashion Textile, LU Feng Co, Alok Industries. Sementara pada penelitian saat ini didapatkan urutan prioritas pemasok sebagai berikut Mastex Inc, Fineline Technologies, Azuma Co, Sunny Fashion Textile, Silverreed Holdings, LU Feng Co, Alok Industries.

Data yang diolah menggunakan Super Decision akan menghasilkan laporan lengkap seperti pada Tabel 8. Sementara data yang diolah menggunakan Microsoft Excel akan menghasilkan urutan prioritas pemasok seperti pada Tabel 7. Perbedaan urutan pemasok terjadi dikarenakan jika menggunakan Super Decision maka hanya digunakan data satu kali penyebaran kuesioner. Sedangkan jika pengolahan data menggunakan Microsoft Excel maka akan digabungkan nilai dari dua kali penyebaran kuesioner. Berdasarkan perbedaan urutan prioritas pemasok tersebut maka dapat disimpulkan jika nilai pakar sangat berpengaruh terhadap urutan prioritas pemasok yang dihasilkan.

Analisis sensitifitas berguna untuk mengetahui bagaimana akibat yang ditimbulkan jika terjadi perubahan parameter terhadap hasil yang akan diperoleh. Pada penelitian ini, parameter yang dirubah ialah menghilangkan salah satu penilaian dari sebuah perusahaan atau lebih. Berdasarkan Gambar 6 maka dapat disimpulkan bahwa nilai consistency ratio jika penilaian dari PT Sri Rejeki Isman Tbk tidak digunakan sebesar 0,0045 lebih kecil daripada nilai consistency ratio jika menggunakan penilaian ketiga perusahaan sebesar 0,0055. Hal ini menunjukkan keputusan yang dihasilkan jika menggunakan seluruh penilaian perusahaan atau menghilangkan salah satu penilaian perusahaan atau menghilangkan salah dua penilaian perusahaan tetap memberikan nilai consistency ratio yang valid. Namun jika hanya menggunakan penilaian dari PT Ungaran Sari Garment dan PT Bina Busana Internusa akan menghasilkan tingkat konsisten lebih baik dikarenakan semakin kecil nilai consistency ratio maka konsistensi suatu penilaian akan semakin konsisten. Sementara urutan prioritas pemasok yang dihasilkan berdasarkan Gambar 12 juga dapat berubah mengikuti perbedaan nilai bobot gabungan yang berbeda. Perbedaan urutan prioritas pemasok ini menunjukkan bahwa nilai bobot yang dijadikan data masukan dalam perhitungan akan sangat mempengaruhi bagaimana hasil yang diperoleh.

\section{KESIMPULAN}

Pada penelitian ini diperoleh urutan prioritas pemasok cadangan yang akan digunakan sebagai pendamping bagi pemasok utama. Pemasok cadangan diurutkan berdasarkan nilai preferensi tertinggi hingga terendah. Urutan prioritas pemasok cadangan diantaranya Mastex Inc dengan nilai preferensi 0,7529 , Fineline Technologies dengan nilai preferensi 0,5690 , Azuma Co dengan nilai preferensi 0,4998, Sunny Fashion Textile dengan nilai preferensi 0,3807, Silverreed Holdings dengan nilai preferensi 0,3686, LU Feng Co dengan nilai preferensi 0,1852, dan Alok Industries dengan nilai preferensi 0,0391. Berdasarkan urutan pemasok tersebut, maka pemasok cadangan akan memenuhi kekurangan pasokan bahan baku berdasarkan dengan urutan prioritas pemasok.

Selain itu, penggunaan metode pengambilan keputusan tidak hanya menggunakan metode Analytical Hierarchy Process (AHP) dan Technique for Others Preference by Similarity to Ideal Solution (TOPSIS). Namun dapat menggunakan metode pengambilan keputusan lain. Berbagai metode tersebut juga dapat dikombinasikan satu sama lain sesuai dengan kebutuhan masalah pengambilan keputusan. Masalah pengambilan keputusan juga tidak hanya pada kasus pemilihan pemasok tetapi juga dapat digunakan pada masalah pengambilan keputusan lain. Penentuan jumlah responden juga dapat disesuaika dengan keperluan penelitian.

\section{DAFTAR PUSTAKA}

Acar, Avni Zafer, Önden, İ., \& Gürel, Ö. (2016). Evaluation of the parameters of the green supplier selection decision in textile industry. Fibres and Textiles in Eastern Europe, 24(5), 8-14. https://doi.org/10.5604/12303666.1215520

Alazzawi, A., \& Zak, J. (2020). MCDM/A Based Design of Sustainable Logistics Corridors Combined with Suppliers Selection. the 
Case Study of Freight Movement to Iraq.

Transportation Research Procedia, 47(2019), 577-584. https://doi.org/10.1016/j.trpro.2020.03.134

Application, E. O. F., \& Saaty, T. L. (1997). Discussion That Is Not the Analytic Hierarchy Process: What the AHP Is and What It Is Not. 1(8), 324-335.

Khurunin, Iin. (2021). Pemilihan Pemasok di Industri Tekstil Jawa tengah menggunakan Analisis Faktor dan TOPSIS. Thesis. UPN "Veteran" Yogyakarta

Mavi, R. K., Goh, M., \& Mavi, N. K. (2016). Supplier Selection with Shannon Entropy and Fuzzy TOPSIS in the Context of Supply Chain Risk Management. Procedia - Social and Behavioral Sciences, 235(October), 216-225. https://doi.org/10.1016/j.sbspro.2016.11.0 17

Pratiwi, Heni. (2016). Buku Ajar Sistem Pendukung Keputusan. Yogyakarta. deepublisher

Rouyendegh (Babek Erdebilli), B. D., \& Saputro, T. E. (2014). Supplier Selection Using Integrated Fuzzy TOPSIS and MCGP: A Case Study. Procedia - Social and Behavioral Sciences, 116, 3957-3970. https://doi.org/10.1016/j.sbspro.2014.01.8 74
Russo, R. D. F. S. M., \& Camanho, R. (2015). Criteria in AHP: A systematic review of literature. Procedia Computer Science, 55(Itqm), $1123-1132$. https://doi.org/10.1016/j.procs.2015.07.08 1

Sakthivel, G., Ilangkumaran, M., \& Gaikwad, A. (2015). A hybrid multi-criteria decision modeling approach for the best biodiesel blend selection based on ANP-TOPSIS analysis. Ain Shams Engineering Journal, 6(1), 239-256. https://doi.org/10.1016/j.asej.2014.08.003

Tamošaitiene, J., Zavadskas, E. K., Šileikaite, I., \& Turskis, Z. (2017). A Novel Hybrid MCDM Approach for Complicated Supply Chain Management Problems in Construction. Procedia Engineering, 172, 1137-1145.

https://doi.org/10.1016/j.proeng.2017.02.1 68

Ulutas, A. (2019). Supplier selection by using a fuzzy integrated model for a textile company. Engineering Economics, 30(5), 579-590.

https://doi.org/10.5755/j01.ee.30.5.20546

Wadi, H. (2020). Sistem Pendukung Keputusan Metode Analythic Hierarchy Process dengan PHP/MYSQL. Jakarta: Turida Publisher. 